\title{
Teaching older workers new tricks: workplace practices and gender training differences in nine European countries
}

\author{
Jelle Lössbroek ${ }^{1 \star}$ and Jonas $\operatorname{Radl}^{2,3}$ \\ ${ }^{1}$ Department of Sociology, Utrecht University, Utrecht, The Netherlands, ${ }^{2}$ Department of Social Sciences, \\ Carlos III University of Madrid, Getafe, Spain and ${ }^{3}$ WZB Berlin Social Science Center, Berlin, Germany \\ ${ }^{\star}$ Corresponding author. Email: j.j.h.lossbroek@uu.nl
}

(Accepted 5 June 2018; first published online 22 August 2018)

\begin{abstract}
Despite its benefits for prolonging careers, participation in training is far lower among older employees (age 50+) than among younger employees. This study analyses gender differences in older employees' training participation. To investigate the predictors of training intensity, we examine two forms of training: formal educational programmes and on-the-job training. The study draws on a novel data-set, the European Sustainable Workforce Survey, carried out in nine European countries in 2015 and 2016, analysing 2,517 older employees and their managers, spread over 228 organisations. We concentrate on the interplay between employees' gender, managers' gender and managers' ageism in shaping older employees' training participation. Our findings indicate comparable training participation of older men and women in both forms of training, yet older women more often pay for enrolment in educational programmes themselves. Also, predictors of training participation are different. In line with the tenet of 'gendered ageism', we find that managerial ageism primarily targets older women, excluding female employees from the training opportunities available to their comparable male colleagues. Finally, female managers are associated with higher training participation rates for older employees, but only for older men. This result supports 'queen bee' arguments and runs counter to 'homophily' arguments. Overall, the study demonstrates that workplace dynamics and managerial decisions contribute to the reproduction of traditional gender divides in the late career.
\end{abstract}

Keywords: training; gender; ageism; international comparison; older employees

\section{Introduction}

Many European governments are facing an ageing population, and stimulate working until a higher age. There is virtual consensus in the literature that a promising avenue to support older employees in working longer is through increased participation in training, either on-the-job or in other forms (Allen and Hart, 1998). This employability-centred approach to retain older workers in the labour market is the

\footnotetext{
(c) Cambridge University Press 2018. This is an Open Access article, distributed under the terms of the Creative Commons Attribution licence (http://creativecommons.org/licenses/by/4.0/), which permits unrestricted re-use, distribution, and reproduction in any medium, provided the original work is properly cited.
} 
socially more sustainable way to postpone retirement than merely to penalise early exit financially ( $c f$. Hofäcker and Radl, 2016). Existing evidence indeed suggests that training older workers effectively leads to more motivated employees (Leppel et al., 2012) and delayed retirement (Fouarge and Schils, 2009; Picchio and Van Ours, 2013). Training has also been shown to yield tangible benefits for workers, as it can contribute to higher wages (Bassanini et al., 2007; Lee, 2009; O'Connell and Byrne, 2012) and job security (Katsimi, 2008).

Yet, there is overwhelming evidence demonstrating that older workers (50+) are less likely to participate in training than younger workers (Armstrong-Stassen and Cattaneo, 2010; Martin et al., 2014; Fleischmann et al., 2015). This lack of lifelong learning is unfortunate because it accelerates the decline of their human capital and undermines efforts to extend working lives. In contrast to this consensus on the 'age-training gap', little is known about which older workers are most likely to continue participating in training. To understand older workers' training participation, this study will focus on gender differences. Although gender is often argued to influence training participation, even basic empirical regularities on gender differences in training participation have not been established unambiguously by previous research. Several studies show that women are under-trained vis-à-vis their male counterparts (Duncan and Hoffman, 1979; Knoke and Ishio, 1998; Frazis et al., 2000; Evertsson, 2004; Dieckhoff and Steiber, 2011). However, it has also been found that female workers are comparatively over-trained (Bassanini et al., 2007; O'Halloran, 2008; Fouarge and Schils, 2009) or that there is no gender training gap (Green and Zanchi, 1997; Karpinska et al., 2015). We argue that gender and age differences should be studied jointly, as several studies have concluded that specifically older women are trained more often than older men (Arulampalam et al., 2004); that female under-training is far larger among younger than among older women (Knoke and Ishio, 1998); and that the age decline in training participation is stronger for men than for women (Carmichael and Ercolani, 2014). Hence, our study aims to contribute new descriptive evidence on gender differences in the continued training of older employees in nine European countries, and more importantly, to establish how organisational characteristics affect men's and women's training participation differently.

At the workplace level, we study two characteristics of managers, who usually are the gatekeepers of training investment decisions (Evertsson, 2004; Karpinska et al., 2015). Firstly, managerial ageism, which arguably particularly hurts older women (Duncan and Loretto, 2004; Barnett, 2005). Secondly, managerial gender, as female managers have both been argued to help female subordinates, due to homophily (a preference for people with whom one shares certain characteristics, such as gender) and having less-sexist attitudes than male managers (Cohen and Huffman, 2007; Dezső et al., 2016), and to hinder female subordinates, via 'queen bee'-related mechanisms (Barreto and Ellemers, 2015; Derks et al., 2016). In short, this paper seeks to answer the following question:

- How can older men's and women's training participation be explained by the interplay between gender and workplace practices?

This study draws on new data from the European Sustainable Workforce Survey (ESWS) (Van der Lippe et al., 2016), which was collected in nine European Union 
countries: Bulgaria, Finland, Germany, Hungary, Netherlands, Portugal, Spain, Sweden and the United Kingdom (UK). This survey includes a total of 259 establishments: questionnaires were filled in by human resources managers about the entire organisation, their almost thousand managers of specific departments and their more than 11,000 employees. The organisations were spread over 18 strata per country: small (40-100 employees), medium (101-250 employees) and large $(251+$ employees) organisations in six occupational sectors. This novel data source extends the current field by combining three key strengths. First, it allows us to innovatively connect information about the employees and about the organisations they work for, acknowledging that training decisions result from an interplay between these levels (Carmichael and Ercolani, 2014). Notably, most previous research on training older workers is based on managerial surveys (ArmstrongStassen and Templer, 2005) or managerial vignette studies (Lazazzara et al., 2013; Karpinska et al., 2015; Fleischmann and Koster, 2018), incapable of examining employee initiatives, or based on population surveys, incapable of examining the role of organisations (Cully et al., 2000; Taylor and Urwin, 2001; Fouarge and Schils, 2009; Canduela et al., 2012; Carmichael and Ercolani, 2014). Second, the ESWS captures the intensity of training participation, whereas previous studies on training participation tend to be restricted to the incidence of training (e.g. whether respondents participated in any training in the previous period). By being able to account for the number of days subjects were training thus overcomes one of the key data limitations of previous research (O'Halloran, 2008; Carmichael and Ercolani, 2014). Third, as the sample spans nine countries and six economic sectors, variations across national settings and industries can be accounted for (Carmichael and Ercolani, 2014). Our final samples includes 228 organisations, 757 department managers and 2,517 employees aged 50 and older.

\section{Explaining older workers' training participation}

To understand training participation of older men and women, we analyse both employee and employer factors. Some argue that lower training participation among older workers is primarily due to employers less often offering training to them (Taylor and Urwin, 2001; Evertsson, 2004); others emphasise that older workers are less eager to participate in training offered to them (for an overview, see Carmichael and Ercolani, 2014). We follow previous studies (Carmichael and Ercolani, 2014; Fleischmann and Koster, 2018) in occupying a middle position: training participation likely shows mutual agreement, as employers often bear a large part of the training costs and know that involuntary training participation is not cost-effective. We study two types of training participation: (a) formal enrolment in educational programmes, and (b) on-the-job training, either by external trainers or by colleagues/managers. Notably, the costs to the organisation for both types of training can vary greatly depending on the number of working hours dedicated to training (which could be zero if the training is fully in the employee's free time); the value of foregone working hours to the employer; the tariff or salary of the external or internal trainer; the height of tuition fees; and the degree to which the employer pays for the training. Previous studies indicate that employers usually pay the majority of the costs (Leuven and Oosterbeek, 1999; 
Bassanini et al., 2007) and that managers believe training older workers is more expensive (Armstrong-Stassen and Cattaneo, 2010; Van Dalen et al., 2015). In the following sections, we develop testable hypotheses on older workers' training that involve the interplay between employee gender, a proxy for manager's ageism and the manager's gender.

\section{Employee gender}

Studies on training participation have provided several explanations of existing gender disparities. Some reported differences are argued to stem from methodological issues, including what kinds of training are considered, what different countries are studied and what time periods are covered (Dieckhoff and Steiber, 2011). Moreover, the training literature is largely confined to workers, and work-force participation is higher among men in virtually all countries, although the gap is narrowing. Still, there are also several theoretical reasons to expect gender differences in training. We summarise theoretical arguments for opposing hypotheses, starting with lower female training.

Arguments explaining that women are under-trained are often based on human capital theory, which can be seen as the dominant approach in explaining training participation (Knoke and Ishio, 1998; Urwin, 2006; O'Connell and Byrne, 2012; Carmichael and Ercolani, 2014). From this theory, several mechanisms have been derived, which could be called the 'work-floor presence' argument (Leuven, 2005; Fouarge and Schils, 2009). At the core of this employer-centred perspective, training is an investment that costs time and money, but yields more productive employees. The more hours employees spend at the work floor after the training, the greater the return on investment. Hence, investments are in part based on the expected time the carrier of human capital will be present on the work floor. In a form of statistical discrimination, employers may believe this expected time is lower for women than for men due to earlier retirement and greater likelihood to work part-time. Women tend to retire earlier than men (Van Dalen et al., 2010; Radl, 2013a), due to a combination of different legal arrangements and personal preferences (such as a desire to retire simultaneously with an often-older partner). Multiple studies show that employers are less likely to offer training to older workers because the period they benefit from it is shorter (McNair et al., 2007; Martin et al., 2014; De Grip et al., 2015); this consideration plausibly undermines training participation even more starkly among older women than among older men. Additionally, women are more likely to shift to working part-time. Indeed, part-time workers, among whom women are over-represented, receive less training (Arulampalam et al., 2004; Evertsson, 2004; O'Halloran, 2008; Dieckhoff and Steiber, 2011; Carmichael and Ercolani, 2014). In brief, employers expecting women to have a lower expected work-floor presence may be less inclined to offer them training. A second argument to expect lower female training based on the human capital approach is employers more often offer training to higher educated employees based on the belief that they are more efficient learners (Arulampalam et al. 2004; Bassanini et al. 2007; Carmichael and Ercolani 2014; Dieckhoff and Steiber 2011; Fouarge and Schils 2009). In nearly all European countries, men are higher educated than women in the current $50+$ cohort, which could lead to lower female training (Van Hek et al. 2016). 
Additionally, given persistent gender discrimination in other labour market processes (Azmat and Petrongolo, 2014), it is also plausible to expect to observe outright sexist discrimination in training measures that goes beyond any productivity concerns.

Finally, female undertraining may be induced by occupational gender segregation, i.e. male workers being more likely to have jobs in which training participation is higher. Workers occupying upper echelons of the occupational hierarchy are likely perceived to have a positive disposition to learning. This signal may be especially important for older workers, as many managers believe that for older workers, the average training capability is lower, but the variance is higher (Steinberg et al., 1996; Brooke and Taylor, 2005; Kluge and Krings, 2008; Martin et al., 2014; De Grip et al., 2015). Indeed, higher training participation has been found for jobs with greater skill intensity (Bassanini et al., 2007), for jobs requiring skill-upgrading (Arulampalam et al., 2004) and for non-blue-collar jobs (Dieckhoff and Steiber, 2011). It is widely recognised that men are more likely than women to advance on the occupational ladder. Women's career progression is hampered both at higher management levels (the 'glass ceiling') and at the employee level (the 'sticky floor') (Pekkarinen and Vartiainen, 2006; Yap and Konrad, 2009). Hence, it has been argued, a gender training gap is in part the result of different promotion chances at different levels of the occupational structure (Pekkarinen and Vartiainen, 2006).

In sum, based on human capital considerations, sexism and occupational gender segregation, we hypothesise:

- Hypothesis 1a: Older workers' training participation rate is lower for women than for men.

The contrary argument, that older women are trained more than men (Fouarge and Schils, 2009; O'Halloran, 2008), can also be founded on various plausible mechanisms: compositional sector differences, a desire to 'catch up' and selection. A compositional argument is that training participation is higher in the public sector than in the private sector (Arulampalam et al., 2004; Karpinska et al., 2015; O'Connell and Byrne, 2012), and women more often work in the public sector than men (Arulampalam et al., 2004). Moreover, many women have had fewer training opportunities early in their career as they have made a career interruption or switched to working fewer hours to accommodate their child-care activities. Older mothers have been found to 'make up' for employment interruptions by delaying retirement (Hank, 2004); this possibly also creates a greater need to catch up with new developments and update the skill-set accordingly. Lastly, because work-force participation is generally lower for older women than for older men (Van Dalen et al., 2010; Van Oorschot and Jensen, 2009), the women who work may be a selective sub-group of highly committed employees (Van Dalen et al., 2010; Radl, 2013b). Based on these three mechanisms (public sector, compensation, selection), we develop an alternative hypothesis:

- Hypothesis 1b: Older workers' training participation rate is higher for women than for men. 


\section{Gendered ageism}

Managers may be influenced by ageist and sexist stereotypes in their decisions about employee training participation. Various studies show that many managers exclude older workers from training based on the notion that they are less able or willing to be trained. Although empirical research on older employee motivation has yielded mixed results, such stereotypes plausibly influence personnel policy nevertheless (Gringart et al., 2005; Loretto and White, 2006; Ng and Feldman, 2012).

Like any type of discrimination, ageism does not exist in a void. Rather, ageism intersects with other discriminatory attitudes, such as sexism. 'Gendered ageism' may influence older women more strongly than older men for various reasons. First, because compared to men, women are more strongly judged on youth-based physical attractiveness (Duncan and Loretto, 2004). This gendered ageism is reinforced by a popular culture displaying ageing of women more negatively than ageing of men (Calasanti, 2005; Duncan and Loretto, 2004). Finally, negative ageist stereotypes are partially counterbalanced by positive stereotypes valuing experience - yet this appreciation is far stronger for older men than for older women (Barnett, 2005). In spite of a higher life expectancy, women are thus generally deemed to be 'old' at a lower age than men. Indeed, Radl (2012) shows that women are believed to become 'too old to work' at a significantly younger age than men. Moreover, women themselves have often internalised this gendered age norm and generally agree that men should work longer than women.

Based on the pervasiveness of gendered ageism, we hypothesise that older women are more structurally targeted by ageist stereotypes than older men.

- Hypothesis 2: The negative influence of managerial ageism on training participation is greater for women than for men.

\section{Managerial gender}

Finally, the extent to which managers treat older men and older women differently may be conditional upon their own gender. Based on the literature, again, we develop two competing hypotheses.

Female managers may be associated with higher training rates for older women through four mechanisms (or a combination thereof): less sexist attitudes, homophily, a desire for gender equality and the organisational climate. First, managerial sexism is one of the hurdles that women need to overcome: sexist stereotypes often portray female workers as less valuable to the organisation than comparably performing male workers. Hence, the extent to which a particular manager holds sexist beliefs can be of major impact on women's opportunities. Even 'benevolent' sexism has been found to hamper female worker's development opportunities (King et al., 2012). Although anyone can be (subconsciously) influenced by sexist ideas, it is plausible that female managers exhibit less traditionally sexist ideas, as their personal experiences have made them more aware of their existence (Cohen and Huffman, 2007). Second, the homophily mechanism (also known as homosocial reproduction mechanism) argues that people tend to subconsciously develop more positive feelings towards people who are like them. Because of this basic 
human tendency, it could be expected that male employees benefit from having a male manager, and female employees benefit from having a female manager (Elliott and Smith, 2004; Roth, 2004; Cohen and Huffman, 2007). This differential appreciation plausibly translates into gender-graded training opportunities. Third, female managers have been argued to be more in favour of special efforts supporting women, to reduce gender inequality (Cohen and Huffman, 2007; Dezsö et al., 2016). It is likely that managers who favour special measures are also more inclined to use existing instruments, such as training arrangements, fostering gender equality. Fourth, the presence of female managers may be an indication of a general organisational climate of gender equality, which allows women to strive professionally. In this line of reasoning, managers are conceptualised as a channel for organisational norms rather than agents. Even without an active influence of female managers, the gender-equal environment that allowed them to occupy their position may also give female employees better access to training and hence contribute to older women 'catching up' with older men. These four arguments are corroborated by studies showing that having a female manager can increase women's performance evaluations (Roth, 2004) and wages for low-qualified women (Abendroth et al., 2016) or all women (Cohen and Huffman, 2007). Hence, we hypothesise:

- Hypothesis 3a: Female managers are more likely to offer training to older women than to older men.

Alternatively, the literature offers two 'queen bee'-related arguments why female managers could be particularly beneficial for (older) men: perceived threat and signalling non-favouritism. The first, most extreme mechanism, is that environments which are dominated by male managers may offer unique advantages to the few managers who are female, such as being more visible due to being exceptional (Dezső et al., 2016). Since these (perceived) advantages may wane if more women ascend the organisational hierarchy, 'queen bee' managers may perceive ambitious female subordinates as a threat and be less willing to support their training. Sexist environments have been found to contribute to female managers adopting this role (Derks et al., 2011). In a second, more nuanced way, queen bee behaviour is born out of a desire for self-preservation rather than self-advancement (Derks et al., 2016). Women (like other marginalised groups) often face repercussions when trying to advocate for more equitable treatment (Barreto and Ellemers, 2015). This is particularly challenging for female managers, who due to prevalent sexism, are under higher levels of scrutiny than their male counterparts (Derks et al., 2016). In order to prevent being perceived as a manager who favours fellow women, female managers may 'over-compensate' by being more favourable towards male subordinates than towards female subordinates (Dezső et al., 2016). It has been found that men experience more job-related support from female managers (Maume, 2011). Additionally, when women have a female manager, they report lower job satisfaction (Artz and Taengnoi, 2016) and receive less training (Halldén, 2015) (while in both studies, managerial gender did not influence male workers). Although the latter only concerns 'initial on-the-job training' and the author tentatively interprets this as a selection effect, this evidence is consistent with the queen bee concept. Based on these two mechanisms, we hypothesise: 
- Hypothesis 3b: Female managers are more likely to offer training to older men than to older women.

\section{Data and methods}

\section{Data}

We use data from the European Sustainable Workforce Survey (ESWS), which were gathered in the years 2015 and 2016 in nine European countries: Bulgaria, Finland, Germany, Hungary, Netherlands, Portugal, Spain, Sweden and the UK (Van der Lippe et al., 2016). Within organisations that agreed to participate, the response rate was 61 per cent for employees, 81 per cent for department managers and 98 per cent for human resources managers; these three types of respondents each received different questionnaires. Out of 3,145 employees aged 50+, 2,517 remained after listwise deletion of missing values, clustered within 757 departments in 228 organisations, varying between 131 employees in Spain and 728 in the Netherlands. This sample is used for Tables 1, 2 and 3 and Figure 1. For our regression analyses in Table 4 and Figure 2, the non-response among department managers narrows down our sample size to 2,093.

\section{Operationalisation}

Below, the operationalisation of each variable is discussed. Questionnaire phrasing and descriptive statistics can be found in Table 1.

\section{Dependent variables}

Two different measures of training participation are used. First, whether the employee has enrolled in an educational programme in the past five years. Second, how many days they were trained in the past year. The questionnaire asks separately for training by a professional, external instructor and for training by a manager or colleague, but since our theoretical expectations are the same for both variables, we add the number of 'external' and 'internal' training days into a single on-the-job training variable. Data limitations have often restricted scholars to studying the incidence of training (Dieckhoff and Steiber, 2011) rather than the intensity of training (O'Halloran, 2008). Thus, it is one of the strengths of the data that it allows analysis of the number of days of training.

\section{Independent variables}

On the individual level, employee gender is measured by a dummy variable indicating whether the respondents consider themselves female. On the department level, the gender of the manager is registered in the same way. Moreover, managerial ageism is proxied by a Likert scale measuring the extent to which the department manager believes older workers are 'biding their time until retirement'.

We control for a range of personal, organisational and job characteristics. Personal characteristics that have been associated with training participation by prior research are age, measured in years (Carmichael and Ercolani, 2014); educational attainment, measured in years of education (Arulampalam et al., 2004; 
Table 1. Descriptive statistics

\begin{tabular}{|c|c|c|c|c|c|}
\hline Variable & Mean & SD & Min & Max & Phrasing \\
\hline \multicolumn{6}{|l|}{ Employee questionnaire $(\mathrm{N}=2,517)$ : } \\
\hline Enrolled in an educational programme & 0.23 & & 0 & 1 & $\begin{array}{l}\text { In the past five years, have you been enrolled in an educational } \\
\text { programme? (0) No, (1) Yes }\end{array}$ \\
\hline Training days in the past year & 3.59 & 9.19 & 0 & 205 & $\begin{array}{l}\text { In the past } 12 \text { months, have you been trained by [a manager or } \\
\text { co-worker]/[a professional instructor from outside the company] }{ }^{1}\end{array}$ \\
\hline Female & 0.54 & & 0 & 1 & Are you male or female? (0) Male, (1) Female \\
\hline Age & 55.83 & 4.39 & 50 & 77 & How old are you? \\
\hline Years of education & 13.28 & 3.37 & 3 & 21 & What is the highest level of education that you have completed? ${ }^{2}$ \\
\hline Health & 2.78 & 0.74 & 0 & 4 & $\begin{array}{l}\text { How is your health in general? Would you say it is (0) Very poor, (1) } \\
\text { Poor, (2) Fair, (3) Good, (4) Very good }\end{array}$ \\
\hline Immigrant & 0.08 & & 0 & 1 & $\begin{array}{l}\text { In which country were you born? (0) [Country of residence], (1) Other, } \\
\text { namely... }\end{array}$ \\
\hline Routine workers & 0.09 & & 0 & 1 & What is your occupation? $?^{3}$ \\
\hline Higher salariat & 0.25 & & 0 & 1 & \\
\hline Lower salariat & 0.28 & & 0 & 1 & \\
\hline Intermediate occupations & 0.19 & & 0 & 1 & \\
\hline Higher grade blue collar & 0.06 & & 0 & 1 & \\
\hline Lower sales and service & 0.08 & & 0 & 1 & \\
\hline Skilled workers & 0.04 & & 0 & 1 & \\
\hline Part-time $(\leq 32)$ & 0.22 & & 0 & 1 & $\begin{array}{l}\text { How many hours are you contracted to work for this organisation? } \\
\text { [If missing:] How many hours do you actually work for this } \\
\text { organisation? [Recoded to }(0)=33+,(1)=\leq 32 \text { ] }\end{array}$ \\
\hline Tenure & 18.02 & 12.06 & 0.08 & 52 & \\
\hline
\end{tabular}


How many years have you been working for this organisation? If you have been working here for less than one year, please indicate the number of months

\begin{tabular}{|c|c|c|c|c|c|}
\hline \multicolumn{6}{|l|}{ Manager questionnaire $\left(\mathrm{N}=757^{4}\right)$ : } \\
\hline Supporting department ${ }^{5}$ & 0.24 & & 0 & 1 & \\
\hline Manager's age & 48.93 & 8.03 & 27 & 71 & How old are you? \\
\hline Female manager & 0.39 & & 0 & 1 & Are you male or female? (0) Male, (1) Female \\
\hline Manager's ageism & 1.34 & 1.01 & 0 & 4 & $\begin{array}{l}\text { Older employees ... are biding their time until retirement (0) Strongly } \\
\text { disagree, (1) Disagree, (2) Neither agree nor disagree, (3) Agree, (4) } \\
\text { Strongly agree }\end{array}$ \\
\hline \multicolumn{6}{|c|}{ Organisation questionnaire $(\mathrm{N}=228)$ : } \\
\hline Organisation size & 5.66 & 1.41 & 2.20 & 9.21 & How many employees are there in your establishment? [log] \\
\hline Public sector & 0.44 & & 0 & 1 & \multirow{3}{*}{$\begin{array}{l}\text { To what sector does your establishment belong? (0) Public, (1) } \\
\text { Private, (2) Mixed (public and private), (3) Other, namely... [combined } \\
\text { (2) and (3) into 'Other sector'] }\end{array}$} \\
\hline Private sector & 0.47 & & 0 & 1 & \\
\hline Other sector & 0.09 & & 0 & 1 & \\
\hline Proportion female employees & 0.51 & 0.25 & 0 & 1 & $\begin{array}{l}\text { What percentage of employees in your establishment ... are female? } \\
\text { [Recoded from an approximately linear nine-point item] }\end{array}$ \\
\hline Netherlands & 0.29 & & & & \multirow[t]{5}{*}{ [Country of the establishment, assigned in data collection] } \\
\hline Germany & 0.10 & & & & \\
\hline Finland & 0.08 & & & & \\
\hline Sweden & 0.13 & & & & \\
\hline United Kingdom & 0.06 & & & & \\
\hline Portugal & 0.08 & & & & \\
\hline
\end{tabular}


Table 1. (Continued.)

\begin{tabular}{llll}
\hline Variable & Mean & SD Min Max & Phrasing \\
\hline Spain & 0.05 & & \\
\hline Hungary & 0.10 & & [Sector of the establishment, assigned in data collection] \\
\hline Bulgaria & 0.10 & \\
\hline Manufacturing & 0.25 & \\
\hline Health care & 0.29 & \\
\hline Higher education & 0.20 & \\
\hline Transport & 0.12 & \\
\hline Financial services & 0.08 & \\
\hline Telecommunication & 0.05 & \\
\hline
\end{tabular}

Notes: 1. Training days = internal + external; if either is missing, only one item is used. 2. Country-specific degrees were harmonised into International Standard Classification of Education codes,

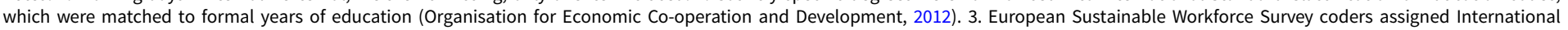
Standard Classification of Occupations (ISCO-08) codes to the occupations, which the authors recoded into the European Socio-economic Classification occupational class

categorisation. 4. Except for manager age, manager female and manager ageism. SD: standard deviation. Min: minimum. Max: maximum. 5. Department is supporting rather than core to the organisation; assigned in data collection.

Source: Authors' calculations based on European Sustainable Workforce Survey. 
Bassanini et al., 2007; Fouarge and Schils, 2009; Dieckhoff and Steiber, 2011; Carmichael and Ercolani, 2014), health (Karpinska et al., 2015) and immigrant status (Yoshida and Smith, 2005; Carmichael and Ercolani, 2014). Organisational characteristics known to influence training participation include firm size, as larger firms tend to offer more training (Carmichael and Ercolani, 2014; Leuven and Oosterbeek, 1999); proportion of female employees; manager age, as older managers are found to give less training to older employees (Karpinska et al., 2015); sector, as substantial sector differences in training participation have been found (Arulampalam et al., 2004; Carmichael and Ercolani, 2014); and country, as large country differences exist too (Bassanini et al., 2007; Carmichael and Ercolani, 2014). Job characteristics associated with training participation are parttime work (Carmichael and Ercolani, 2014; Dieckhoff and Steiber, 2011; O'Halloran, 2008) and job tenure (Arulampalam et al., 2004; Carmichael and Ercolani, 2014; Fouarge and Schils, 2009). For part-time work, if the number of contracted work hours was not available, we relied on reported actual working hours instead. Because of the theoretical role of occupational gender segregation spelled out in the development of Hypothesis 1a, we also include occupational class (Carmichael and Ercolani, 2014), measured through nine European Socio-economic Classification $(\mathrm{ESeC})$ categories, which are an extension of the well-known Erikson-Goldthorpe class scheme (Rose and Harrison, 2007).

\section{Estimation strategy}

Since the dependent variables are measured in different ways, we apply two different estimation strategies for our models. To model enrolment in an educational programme, a binary outcome, we use logistic regression to capture the factors associated with participation. To model training intensity, we use negative binomial regression models on the number of training days in the previous year. The training days variable only contains non-negative, integer values. Also, the distribution of training days is right-skewed rather than normally distributed (i.e. its mean value is substantially larger that its median value). First, many older employees have participated in zero days of training; second, the majority of older employees have participated in a small number of training days. ${ }^{1}$ For these reasons, negative binomial regression has been used to estimate the number of training days previously (Arulampalam and Booth, 1997). To test our hypotheses, we will perform separate analyses for men and women (Arulampalam et al., 2004; Carmichael and Ercolani, 2014; Dieckhoff and Steiber, 2011).

\section{Results}

\section{Descriptive results}

As shown in Table 2, the female enrolment rate in educational programmes is slightly higher than the male enrolment rate; however, the difference is statistically insignificant $^{2}(0.23$ versus 0.22$)$. For training days, women have a higher average number, a difference which is moderate and significant (3.93 versus 3.20). Previous research had indicated a small gender gap for employees (Arulampalam 
Table 2. Country differences in training participation by older men and women

\begin{tabular}{lcccc}
\hline & $\begin{array}{c}\text { Enrolled in an educational } \\
\text { programme (participation rate) }\end{array}$ & Women & $\begin{array}{c}\text { Training days in the past year } \\
\text { (mean days per year) }\end{array}$ \\
\cline { 2 - 5 } & Men & Men & Women \\
\hline Netherlands & 0.26 & 0.29 & 2.34 & 3.11 \\
\hline Germany & 0.22 & 0.18 & 2.91 & 5.80 \\
\hline Finland & 0.11 & 0.26 & 4.23 & 2.72 \\
\hline Sweden & 0.17 & 0.10 & 2.72 & 2.58 \\
\hline United Kingdom & 0.17 & 0.21 & 3.03 & 3.31 \\
\hline Portugal & 0.18 & 0.13 & 3.68 & 8.03 \\
\hline Spain & 0.34 & 0.19 & 7.94 & 4.75 \\
\hline Hungary & 0.28 & 0.27 & 4.05 & 3.36 \\
\hline Bulgaria & 0.24 & 0.26 & 2.90 & 3.93 \\
\hline Total & 0.22 & 0.23 & 3.20 & 23 \\
\hline
\end{tabular}

Note: $\mathrm{N}=2,517$.

Source: Authors' calculations based on European Sustainable Workforce Survey.

et al., 2004), but did not include employees aged 55-64. An analysis of the younger employees (age <50; not shown) reveals an overall higher training participation with no significant gender gap, for both indicators. Additionally, training participation is broken down by country, showing substantial variance in general levels of training among older workers, albeit without clear regional patterns. For instance, Spain and Hungary score relatively high on both items, whereas Portugal, Sweden and the UK score relatively low on both items. Although gender differences depend on which training item is analysed in each country, women score higher than men on both indicators in Bulgaria, Finland and the Netherlands. These within-country gender differences are not statistically significant, except for enrolment in Finland and on-the-job training in Germany, which is likely partly due to limited statistical power. For the other countries, the picture is mixed. This is in line with the observation by Dieckhoff and Steiber (2011) that the literature's inconclusiveness on the training gender gap may be the result of analysing different training indicators in different countries. The evidence is not clear enough to support either Hypothesis 1a or Hypothesis $1 \mathrm{~b}$.

Figure 1 shows that although enrolment in educational programmes is on comparable levels for men and women, there are substantial differences in funding among those older employees who enrol. Older men significantly more often get all enrolment costs refunded by their employers, whereas older women significantly more often pay everything themselves. A speculative interpretation of this finding is that more women seem to be willing to pay for additional education themselves seeing that their employers are not ready to sponsor their further education.

Figure 2 displays country differences in managerial ageism, as proxied by the ageist belief that older workers are 'biding their time'. On average, ageist 


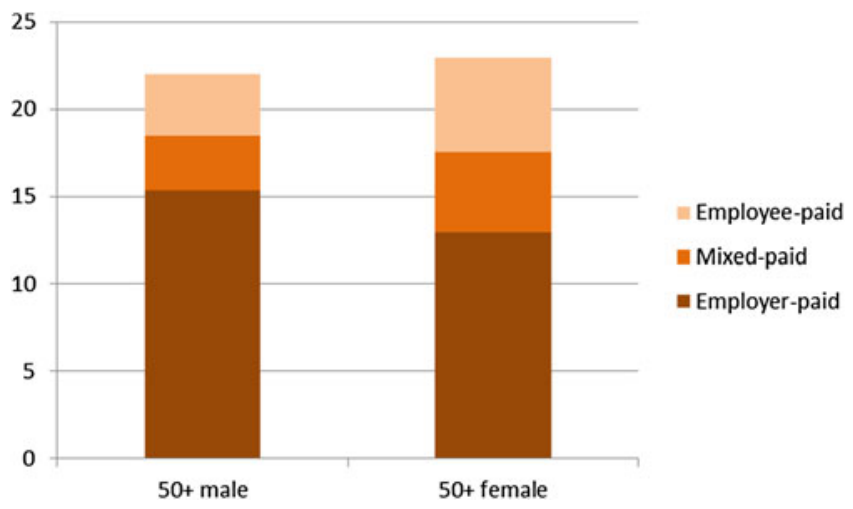

Figure 1. Distribution of costs of educational programme enrolment.

Note: The figure shows the percentages of older employees enrolled in employer-paid, mixed-paid or employee-paid educational programmes in the past five years.

Source: Authors' calculations based on the European Sustainable Workforce Survey.

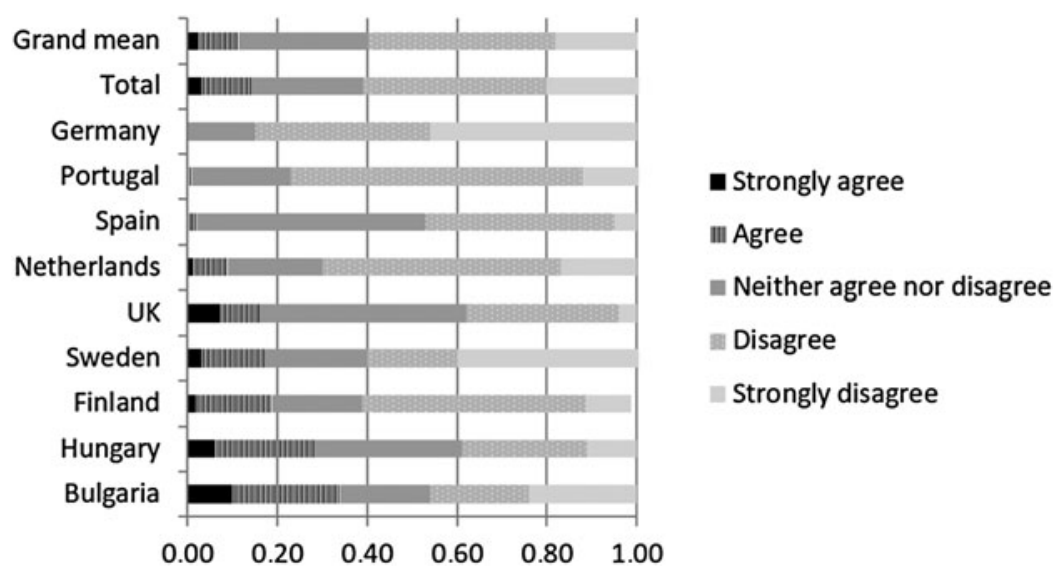

Figure 2. Country differences in managers' ageism.

Notes: Countries are ranked by proportion of older workers with a manager answering 'Strongly agree + Agree'. Original phrasing of question asked to department managers: 'Older workers are biding their time until retirement'. UK: United Kingdom.

stereotypes seem to be relatively less prevalent in Western European countries (Germany, Netherlands) and Southern European countries (Portugal, Spain), and relatively higher in the UK, Northern European countries (Finland, Sweden) and particularly in Eastern European countries (Hungary, Bulgaria). These cross-national differences should be interpreted in the light of not completely country-representative data and of possible social desirability bias influencing our findings. Nevertheless, given the stark contrasts-over 30 per cent of Bulgarian managers and 0 per cent of German managers (strongly) agree with our ageist question - we think that it is plausible that our data reflect real differences in age-related stereotypes. 


\section{Analytical results}

In Table 3, we show estimation results from the multivariate models. It turns out that the effect of gender on training participation changes depending on the measure used as well as other variables included in the models. In the estimated models of enrolment in educational programmes, there is no significant gender effect in the personal characteristics model (column T3a). Once organisation characteristics are controlled for (column T3b), a substantial negative coefficient for being female shows up, but the inclusion of job characteristics (column T3c) negates the gender effect. This indicates that women are over-represented in organisations which offer more educational programmes in general, yet within these organisations, they are less likely to be selected for such programmes than their male colleagues. In the estimated models of participation in on-the-job training, the models build up in the same way. The effect of being female is significantly positive in the base specification (column T3d). After organisation characteristics (column T3e) and job characteristics (column T3f) are included, the effect for being female disappears. This, again, indicates that women are over-represented in organisations which offer more on-the-job training in general, yet within these organisations, they receive the same amount of training as their male colleagues. ${ }^{3}$ Based on these results, it should be stressed that analyses on training intensities should account for the important role of organisational and job characteristics in understanding gender differences.

Inspecting the coefficients pertaining to the control variables, we see that even though we selected only employees older than 50, age still has a negative effect on training participation. The sample selection plausibly also contributed to the small and non-significant effect of educational attainment: the productivity of initial educational degrees may have waned over the ensuing decades of work experience. Moreover, we simultaneously control for occupational class, which arguably has a more direct influence on training opportunities. Indeed, occupational class has a more substantial effect on training participation than education. Employee health, tenure, part-time status and immigration status do not significantly influence training participation of either kind. On the organisational level, larger firms offer more educational programmes and more on-the-job training. The estimates for the country differences show the same pattern as those in Table 2, suggesting that country differences can only to a small extent be explained by compositional effects. Sectoral differences are rather small for on-the-job training, but large for enrolment in educational programmes: compared to the reference category of manufacturing, enrolment in educational programmes rates are higher in health care, higher education, transport and particularly financial services.

In Table 4, we test Hypotheses 2, 3a and 3b by focusing on the (gender-specific) effects of the characteristics of managers: managerial age-discriminatory attitudes and managerial gender. As before, regression results are presented for educational programme enrolment and on-the-job training among 50+ employees. These coefficients are adjusted for all variables included in the final models of Table 3 and additionally for the age of the manager; the control variables performed similarly to the final models of Table 3 (results not shown but available upon request). In the sub-sample of older male employees, managerial ageism has no effect on training participation (columns T4a 
Table 3. Regression results on the predictors of two measures of training participation among older employees

\begin{tabular}{|c|c|c|c|c|c|c|}
\hline & \multicolumn{3}{|c|}{ Enrolled in an educational programme } & \multicolumn{3}{|c|}{ Training days in the past year } \\
\hline & T3a & $\mathrm{T} 3 \mathrm{~b}$ & $\mathrm{~T} 3 \mathrm{c}$ & T3d & T3e & T3f \\
\hline \multicolumn{7}{|l|}{ Personal characteristics: } \\
\hline Female & 0.010 & $-0.250^{*}$ & -0.104 & $0.198^{*}$ & -0.024 & 0.013 \\
\hline Age & $-0.047^{\star \star \star}$ & $-0.050^{\star * *}$ & $-0.048^{\star \star \star}$ & $-0.034^{\star \star \star}$ & $-0.031^{\star \star *}$ & $-0.033^{\star \star *}$ \\
\hline Years of education & 0.015 & 0.009 & 0.019 & 0.022 & 0.017 & -0.016 \\
\hline Health & -0.019 & -0.003 & 0.010 & 0.020 & 0.078 & 0.039 \\
\hline Immigrant & 0.006 & 0.202 & 0.109 & -0.275 & -0.125 & -0.071 \\
\hline \multicolumn{7}{|c|}{ Organisation characteristics: } \\
\hline Proportion female & & -0.418 & -0.371 & & $0.563^{*}$ & $0.679^{\star \star}$ \\
\hline Organisation size (log) & & $0.108^{\star \star}$ & $0.117^{\star \star}$ & & $0.106^{\star * \star}$ & $0.115^{\star \star *}$ \\
\hline \multicolumn{7}{|c|}{ Country (Ref. Netherlands): } \\
\hline Germany & & $-0.513^{\star}$ & $-0.698^{\star \star \star}$ & & $0.432^{\star \star}$ & $0.374^{\star}$ \\
\hline Finland & & -0.380 & $-0.575^{\star}$ & & $0.462^{\star \star}$ & $0.365^{\star}$ \\
\hline Sweden & & $-0.675^{\star \star \star}$ & $-0.805^{\star \star \star}$ & & 0.190 & 0.212 \\
\hline United Kingdom & & -0.322 & -0.493 & & 0.138 & 0.158 \\
\hline Portugal & & $-0.852^{\star \star \star}$ & $-1.089^{\star \star \star}$ & & $0.418^{\star \star}$ & 0.297 \\
\hline Spain & & -0.076 & -0.204 & & $1.103^{\star \star \star}$ & $0.975^{\star \star *}$ \\
\hline Hungary & & 0.295 & 0.040 & & $0.658^{\star \star \star}$ & $0.622^{\star \star \star}$ \\
\hline Bulgaria & & 0.074 & -0.193 & & 0.231 & 0.128 \\
\hline \multicolumn{7}{|c|}{ Occupational sector (Ref. Manufacturing) } \\
\hline Health care & & $0.788^{\star \star}$ & $0.896^{\star \star \star}$ & & 0.090 & 0.021 \\
\hline
\end{tabular}


Table 3. (Continued.)

\begin{tabular}{|c|c|c|c|c|c|c|}
\hline & \multicolumn{3}{|c|}{ Enrolled in an educational programme } & \multicolumn{3}{|c|}{ Training days in the past year } \\
\hline & T3a & $\mathrm{T} 3 \mathrm{~b}$ & $\mathrm{~T} 3 \mathrm{c}$ & $\mathrm{T} 3 \mathrm{~d}$ & T3e & T3f \\
\hline Higher education & & $0.567^{\star}$ & $0.681^{\star \star}$ & & -0.240 & -0.364 \\
\hline Transport & & $0.407^{\star}$ & $0.380^{\star}$ & & 0.067 & 0.116 \\
\hline Financial services & & $1.146^{\star \star \star}$ & $1.401^{\star \star \star}$ & & 0.316 & 0.195 \\
\hline Telecommunication & & -0.311 & -0.198 & & 0.006 & -0.142 \\
\hline \multicolumn{7}{|l|}{ Sector (Ref. Public sector): } \\
\hline Private sector & & -0.117 & -0.140 & & -0.131 & -0.093 \\
\hline Other sector & & $0.571^{\star \star}$ & $0.507^{\star \star}$ & & 0.175 & 0.260 \\
\hline Supporting department & & -0.141 & -0.085 & & -0.011 & -0.048 \\
\hline \multicolumn{7}{|c|}{ Job characteristics (Ref. Routine): } \\
\hline Higher salariat & & & $-0.505^{\star}$ & & & $1.036^{\star \star \star}$ \\
\hline Lower salariat & & & -0.326 & & & $0.681^{\star * \star}$ \\
\hline Intermediate occupations & & & $-0.824^{\star \star \star}$ & & & $0.551^{\star \star}$ \\
\hline Higher-grade blue collar & & & -0.330 & & & $0.783^{\star \star \star}$ \\
\hline Lower sales and service & & & $-0.575^{\star}$ & & & $0.494^{*}$ \\
\hline Skilled workers & & & 0.107 & & & 0.444 \\
\hline Part-time ( $\leq 32$ hours) & & & -0.264 & & & -0.089 \\
\hline Tenure & & & -0.004 & & & -0.000 \\
\hline Constant & 1.207 & 0.872 & 1.073 & $2.695^{\star \star \star}$ & $1.371^{\star}$ & 1.264 \\
\hline In alpha constant & & & & $1.236^{\star \star \star}$ & $1.166^{\star \star \star}$ & $1.141^{\star \star \star}$ \\
\hline
\end{tabular}

Notes: $\mathrm{N}=2,517$. Ref.: reference category.

Source: Authors' calculations based on European Sustainable Workforce Survey.

Significance levels: ${ }^{\star} p<0.05,{ }^{\star \star} p<0.01,{ }^{\star \star \star}{ }^{*} p<0.001$. 
Table 4. Regression models analysing the influence of managerial characteristics on training participation of older men and women

\begin{tabular}{|c|c|c|c|c|}
\hline \multirow[b]{3}{*}{ Sample } & \multicolumn{2}{|c|}{$\begin{array}{l}\text { Enrolled in an educational } \\
\text { programme }\end{array}$} & \multicolumn{2}{|c|}{ Training days in the past year } \\
\hline & Men & Women & Men & Women \\
\hline & $\mathrm{T} 4 \mathrm{a}$ & $\mathrm{T} 4 \mathrm{~b}$ & $\mathrm{~T} 4 \mathrm{C}$ & $\mathrm{T} 4 \mathrm{~d}$ \\
\hline Employee's age & -0.033 & $-0.056^{\star \star}$ & -0.023 & $-0.041^{\star \star}$ \\
\hline Manager's ageism & -0.110 & $-0.250^{\star \star}$ & -0.011 & $-0.249^{\star \star \star}$ \\
\hline Female manager & 0.269 & 0.030 & $0.598^{\star \star \star}$ & 0.188 \\
\hline Manager's age & -0.012 & -0.005 & $-0.020^{\star}$ & $-0.028^{\star \star \star}$ \\
\hline $\mathrm{N}$ & 960 & 1,134 & 957 & 1,136 \\
\hline
\end{tabular}

Notes: Models control for education, health; native born; share of women in organisation; firm size; country; economic sector; public sector; occupational class; part-time work; tenure. Full results are available upon request.

Source: Authors' calculations based on European Sustainable Workforce Survey.

Significance levels: ${ }^{\star} p<0.05,{ }^{\star \star} p<0.01,{ }^{\star \star \star} p<0.001$.

and T4c), but in the sub-sample of older female employees, managerial ageism has a substantial negative effect on training participation (columns T4b and T4d). Consistent with the notion of 'gendered ageism', these models support Hypothesis 2 in indicating that managerial ageism, indeed, primarily hurts women.

Finally, the gender of the manager has no effect on enrolment in educational programmes, neither for men nor for women. For on-the-job training, the level of training is higher in the departments that have a female manager, which is the case in 39 per cent of our sample. However, this effect is only significant for older men, and not for older women (columns T4c and T4d). This supports the argument that having a female manager is primarily beneficial for male training participation. The 'queen bee' mechanism was found for on-the-job training, and not found for educational programme enrolment; hence, Hypothesis $3 \mathrm{a}$ is rejected and Hypothesis $3 \mathrm{~b}$ is partially supported.

\section{Sensitivity analyses}

To assess the robustness of our findings, we performed several sensitivity analyses (output is available on request). First, we controlled for the weekly hours spent on child care, grandparenting, informal care and household chores. Although older women spend far more hours on household production than men, this did not affect our models in any way. Plausibly, domestic work contributes to different job types and fewer working hours (Barnett, 2005), factors which influence training participation but which are already controlled for in the models. Second, we replicated the models on enrolment in an educational programme, analysing the extent to which the employer paid for enrolment in educational programmes rather than enrolment in itself. We used both ordered logit models to analyse the extent to which organisations paid for enrolment in educational programmes $(0=$ none, $4=$ all) and logistic regression with varying cut-off points. These analyses lead to essentially the same results as the preferred specifications. Third, to exclude the 
possibility of sampling error driving our findings on managers, we ran additional models to predict the extent to which employees 'work on keeping [their] workskills up-to-date' $(0=$ seldom, $5=$ always $)$. All manager characteristics were insignificant here, demonstrating that managers have no effects on independent learning whereas they influence in-house training. Fourth, we replicated the on-the-job training days models using tobit regression analysis rather than negative binomial models. This approach, suggested by Green and Zanchi (1997), supports our conclusions. Fifth, in addition to the commonly applied threshold of age 50, we replicated the models for each age threshold between 45 and 60 years. Effect sizes and/or significance levels of our theoretical variables gradually decreased as thresholds were further away from 50, plausibly induced by including employees not considered to be 'old' (for the lower thresholds) and rapidly shrinking sample size (for the higher thresholds). Sixth, we have analysed educational programme enrolment using linear probability models, as it has been argued that for binary dependent variables with non-extreme probabilities, this approach is preferable to logistic regression (Hellevik, 2009). Results are virtually identical.

\section{Discussion}

An expanding body of literature indicates that training participation for older employees contributes to a broad range of desirable outcomes. For instance, employers benefit from having employees who are more motivated (Leppel et al., 2012), policy makers benefit from having a workforce who wants to work until a higher age (Fouarge and Schils, 2009; Picchio and Van Ours, 2013), and employees benefit from higher wages (Bassanini et al., 2007; Lee, 2009; O'Connell and Byrne, 2012) and job security (Katsimi, 2008). Nevertheless, lifelong learning has remained more a punch word than a reality so far. While it is well-known that older employees receive less training than younger employees, gender differences in training among those older employees are rarely studied. Therefore, this paper analysed to what extent older men and women (age 50+) in nine European countries enrol in educational programmes and participate in on-the-job training, scrutinising the factors that contribute to gender differences in training patterns. We used new and unique manager-employee data from the ESWS to study how older men and women are differentially affected by managerial ageism and managers' gender.

Overall, we found comparable training rates for older men and women for both educational programmes and on-the-job training. Nevertheless, four key findings of this study confirm the central importance of gender in understanding training participation. First, overall similar rates of enrolment in educational programmes obscure the fact that women far more often than men pay for these degrees themselves. Older male employees more frequently receive employer funding to (fully or partially) pay for enrolment fees. This finding is in line with studies on younger employees that indicate that employers pay most of the training costs (Bassanini et al., 2007; Leuven and Oosterbeek, 1999) but that the financial burden for selfpaying employees primarily falls on women (Bassanini et al., 2007). As this study shows, this gender difference is perpetuated for older employees.

Second, the results indicate that the gender training gap is conditional on organisation and job characteristics: older women, on average, work for organisations 
that are more likely to offer training to their staff, for instance in the public sector. However, within these organisations, they tend to have jobs that make them less likely to receive training. This corroborates the argument that women more often have peripheral, low-training jobs (Knoke and Ishio, 1998), and the observation that the gender training gap tends to disappear when job characteristics are added (O'Connell and Byrne, 2012). Evidently, organisations are at the core of the processes driving on-the-job training and should be central in efforts to understand gender differences among older employees.

We also found that existing gender differences are influenced by manager characteristics, and particularly department managers' gender and ageist attitudes. Working for a manager who holds ageist stereotypes does not affect older men, but older women receive less training in these departments. This third key result supports the theorem of 'gendered ageism' stipulating that women are more often socially punished for growing older. Consistent with the notion of intersectionality that stresses the compound effect of various axes of social stratification, this finding confirms that the adverse effects of ageism and sexism do not simply add up, but in conjunction produce greater disadvantages for older women (Barnett, 2005; Duncan and Loretto, 2004).

Fourth, we found that working for a female manager makes older men more likely to receive training vis-à-vis older women. The most plausible interpretation for this novel finding is that female managers hedge against being accused of favouritism towards women, and over-compensate by favouring men. However, the finding is also in line with the 'queen bee' argument implying that minority managers fear that the rise of other minority members threatens their exceptionality and thus their privileged position in the organisational hierarchy (Barreto and Ellemers, 2015; Derks et al., 2016; Dezső et al., 2016).

Several qualifications should be noted on interpreting this study. First, the ESWS data by construction only contain respondents who currently work, which may entail sample selection effects due to survey non-response or lower labour market participation among female, older or less-motivated employees. Hence, our findings cannot be generalised to the entire working-age population. Second, while the ESWS used stratified sampling, the data do not provide a representative overview of all organisations in the nine countries under study. Most notably, as the survey focused on personnel policies usually absent in very small organisations, only organisations with 40 or more employees were included. Although (other than the size criterion) we have no indication that this set-up influences our results, it would be worthwhile to test the hypotheses developed and tested in this study with population-representative data. In view of the pronounced country differences in manager ageism shown by the data, future research is particularly needed to corroborate the presented findings on gendered ageism across varying national contexts. Third, data were collected in the aftermath of the Great Recession. Since training rates are usually lower during financial crises (Green and Zanchi, 1997), labour market scarcity induces investing in older employees (Fleischmann et al., 2015) and gender inequality on the labour market changes over time (Green and Zanchi, 1997), it may be interesting to replicate this study in a different temporal context.

To support prolonged working lives of older employees, there is a continued need to understand which workplace characteristics are capable of fostering a more 
age-friendly environment. It is also necessary to understand better what drives organisations to train their personnel. Unfortunately, the managerial characteristics we found that hamper female training participation are not easy to change through policies. Nevertheless, in the light of our findings, educational interventions, nudges and media campaigns to fight ageism appear to be promising avenues to increase older employees' employability as well as to reduce traditional gender divides in the later career. Diversity training for managers has been suggested as a solution against undertraining, both for female (Knoke and Ishio, 1998) and older employees (Armstrong-Stassen and Templer, 2005). However, a Canadian study suggests that even among organisations in which human resources managers believe such training is important, only a small fraction of organisations actually implemented such training (Armstrong-Stassen and Templer, 2005). Over time, if current trends continue and workplaces with large shares of older employees and female middle managers become the new normal, gendered ageism and over-compensating might lose influence as well. Until then, it may be worth contemplating ways to bypass the undue influence of negative stereotypes by empowering older employees and shifting training decisions away from managers and towards employees themselves.

Financial support. The research leading to these results has received funding from the European Research Council under the European Union's Seventh Framework Programme (FP/2007-2013)/ERC grant agreement number 340045. The authors also acknowledge support by European Cooperation in Science in Technology through COST Action IS1409.
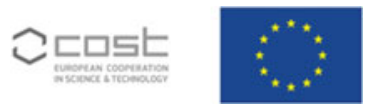

\section{NOTES}

1 Since the variance is significantly larger than the mean $(p<0.001)$, negative binomial regression is preferable over Poisson regression.

2 In the Descriptive Results section, all statements about statistical significance refer to two-tailed $t$-tests with significance thresholds of 0.05 .

3 An additional analysis indicates that on the organisation level, the proportion of female workers and the training measures are positively correlated, although the Pearson correlation is only significant for training days in the past year. These correlations are line with the findings of Table 3.

\section{References}

Abendroth AK, Melzer S, Kalev A and Tomaskovic-Devey D (2016) Women at work: women's access to power and the gender earnings gap. Industrial and Labor Relations Review 70, 190-222.

Allen JM and Hart M (1998) Training older workers: implications for HRD/HPT professionals. Performance Improvement Quarterly 11, 91-102.

Armstrong-Stassen M and Cattaneo J (2010) The effect of downsizing on organizational practices targeting older workers. Journal of Management Development 29, 344-363.

Armstrong-Stassen $\mathbf{M}$ and Templer A (2005) Adapting training for older employees: the Canadian response to an aging workforce. Journal of Management Development 24, 57-67.

Artz B and Taengnoi S (2016) Do women prefer female bosses? Labour Economics 42, 194-202.

Arulampalam W and Booth AL (1997) Who gets over the training hurdle? A study of the training experiences of young men and women in Britain. Journal of Population Economics 10, 197-217.

Arulampalam W, Booth AL and Bryan ML (2004) Training in Europe. Journal of the European Economic Association 2/3, 346-360.

Azmat G and Petrongolo B (2014) Gender and the labor market: what have we learned from field and lab experiments? Labour Economics 30, 32-40. 
Barnett RC (2005) Ageism and sexism in the workplace. Generations 29, 3, 25-30.

Barreto M and Ellemers N (2015) Detecting and experiencing prejudice: new answers to old questions. Advances in Experimental Social Psychology 52, 139-219.

Bassanini A, Booth AL, Brunello G, De Paola M and Leuven E (2007) Workplace training in Europe. Institute for the Study of Labor, Discussion Paper IZA 1640.

Brooke L and Taylor P (2005) Older workers and employment: managing age relations. Ageing \& Society 25, 415-429.

Calasanti T (2005) Ageism, gravity and gender: experiences of aging bodies. Generations 29, 8-12.

Canduela J, Dutton M, Johnson S, Lindsay C, McQuaid RW and Raeside R (2012) Ageing, skills and participation in work-related training in Britain: assessing the position of older workers. Work, Employment \& Society 26, 42-60.

Carmichael F and Ercolani MG (2014) Age-training gaps in the European Union. Ageing \& Society 34, 129-156.

Cohen PN and Huffman ML (2007) Working for the woman? Female managers and the gender wage gap. American Sociological Review 72, 681-704.

Cully M, VandenHeuvel A, Curtain R and Wooden M (2000) Participation in, and barriers to, training: the experience of older adults. Australasian Journal on Ageing 19, 172-179.

De Grip A, Fouarge D and Montizaan R (2015) Goede inzetbaarheid oudere medewerkers vereist beter HR-beleid. Tilburg, The Netherlands: Netspar.

Derks B, Ellemers N, Van Laar C and de Groot K (2011) Do sexist organizational cultures create the Queen Bee? British Journal of Social Psychology 50, 519-535.

Derks B, Van Laar C and Ellemers N (2016) The queen bee phenomenon: why women leaders distance themselves from junior women. Leadership Quarterly 27, 456-469.

Dezső CL, Ross DG and Uribe J (2016) Is there an implicit quota on women in top management? A largesample statistical analysis. Strategic Management Journal 37, 98-115.

Dieckhoff $\mathbf{M}$ and Steiber $\mathbf{N}$ (2011) A re-assessment of common theoretical approaches to explain gender differences in continuing training participation. British Journal of Industrial Relations 49, s1, s135-157.

Duncan C and Loretto W (2004) Never the right age? Gender and age-based discrimination in employment. Gender, Work and Organisation 11, 95-115.

Duncan GJ and Hoffman S (1979) On-the-job training and earnings differences by race and sex. Review of Economics and Statistics 61, 594-603.

Elliott JR and Smith RA (2004) Race, gender, and workplace power. American Sociological Review 69, 365-386.

Evertsson M (2004) Formal on-the-job training: a gender-typed experience and wage-related advantage? European Sociological Review 20, 79-94.

Fleischmann M and Koster F (2018) Older workers and employer-provided training in the Netherlands: a vignette study. Ageing \& Society 38, 1995-2018.

Fleischmann M, Koster F and Schippers J (2015) Nothing ventured, nothing gained! How and under which conditions employers provide employability-enhancing practices to their older workers. International Journal of Human Resource Management 26, 2908-2925.

Fouarge D and Schils T (2009) The effect of early retirement incentives on the training participation of older workers. Labour 23, special issue, 85-109.

Frazis H, Gittleman M and Joyce $\mathbf{M}$ (2000) Correlates of training: an analysis using both employer and employee characteristics. Industrial and Labor Relations Review 53, 443-462.

Green F and Zanchi L (1997) Trends in the training of male and female workers in the United Kingdom. British Journal of Industrial Relations 35, 635-644.

Gringart E, Helmes E and Speelman CP (2005) Exploring attitudes towards older workers among Australian employers. Journal of Aging and Social Policy 17, 85-103.

Halldén K (2015) Taking training to task: sex of the immediate supervisor and men's and women's time in initial on-the-job training. Work and Occupations 42, 73-102.

Hank K (2004) Effects of early life family events on women's late life labour market behaviour: an analysis of the relationship between childbearing and retirement in Western Germany. European Sociological Review 20, 189-198.

Hellevik O (2009) Linear versus logistic regression when the dependent variable is a dichotomy. Quality and Quantity 43, 59-74. 
Hofäcker D and Radl J (2016) Retirement transitions in times of institutional change. In Hofäcker D, Hess M and König S (eds), Delaying Retirement: Progress and Challenges of Active Ageing in Europe, the United States and Japan. London: Palgrave Macmillan, pp. 1-21.

Karpinska K, Henkens K, Schippers J and Wang M (2015) Training opportunities for older workers in the Netherlands: a vignette study. Research in Social Stratification and Mobility 41, 105-114.

Katsimi M (2008) Training, job security and incentive wages. Scottish Journal of Political Economy 55, 67-78.

King EB, Botsford W, Hebl MR, Kazama S, Dawson JF and Perkins A (2012) Benevolent sexism at work: gender differences in the distribution of challenging developmental experiences. Journal of Management 38, 1835-1866.

Kluge A and Krings F (2008) Attitudes towards older workers and Human Resource practices. Swiss Journal of Psychology 67, 61-64.

Knoke D and Ishio Y (1998) The gender gap in company job training. Work and Occupations 25, 141-167.

Lazazzara A, Karpinska K and Henkens K (2013) What factors influence training opportunities for older workers? Three factorial surveys exploring the attitudes of HR professionals. International Journal of Human Resource Management 24, 2154-2172.

Lee DS (2009) Training, wages, and sample selection: estimating sharp bounds on treatment effects. Review of Economic Studies 76, 1071-1102.

Leppel K, Brucker E and Cochran J (2012) The importance of job training to job satisfaction of older workers. Journal of Aging and Social Policy 24, 62-76.

Leuven E (2005) The economics of private sector training: a survey of the literature. Journal of Economic Surveys 19, 91-111.

Leuven E and Oosterbeek H (1999) Demand and supply of work-related training: evidence from four countries. In Polacheck S and Robst J (eds), Research in Labor Economics. Greenwich, United States: Emerald Group Publishing Limited, pp. 303-330.

Loretto W and White P (2006) Employers' attitudes, practices and policies towards older workers. Human Resource Management Journal 16, 313-330.

Martin G, Dymock D, Billett S and Johnson G (2014) In the name of meritocracy: managers' perceptions of policies and practices for training older workers. Ageing \& Society 34, 992-1018.

Maume DJ (2011) Meet the new boss ... same as the old boss? Female supervisors and subordinate career prospects. Social Science Research 40, 287-298.

McNair S, Flynn M and Dutton N (2007) Employer Responses to an Ageing Workforce: A Qualitative Study. Leeds, UK: Department for Work and Pensions.

Ng TWH and Feldman DC (2012) Evaluating six common stereotypes about older workers with meta-analytical data. Personnel Psychology 65, 821-858.

O'Connell PJ and Byrne D (2012) The determinants and effects of training at work: bringing the workplace back in. European Sociological Review 28, 283-300.

O'Halloran PL (2008) Gender differences in formal on-the-job training: incidence, duration, and intensity. Labour 22, 629-659.

Organisation for Economic Co-operation and Development (2012) PISA 2012 Technical Report. Paris: Organisation for Economic Co-operation and Development.

Pekkarinen T and Vartiainen J (2006) Gender differences in promotion on a job ladder: evidence from Finnish metalworkers. Industrial and Labor Relations Review 59, 285-301.

Picchio M and Van Ours JC (2013) Retaining through training even for older workers. Economics of Education Review 32, 29-48.

Radl J (2012) Too old to work, or too young to retire? The pervasiveness of age norms in Western Europe. Work, Employment \& Society 26, 755-771.

Radl J (2013a) Labour market exit and social stratification in Western Europe: the effects of social class and gender on the timing of retirement. European Sociological Review 29, 654-668.

Radl J (2013b) Why do women in Spain retire later than men? Revista española de investigaciones sociológicas 142, 109-122.

Rose D and Harrison E (2007) The European socio-economic classification: a new social class schema for comparative European research. European Societies 9, 459-490.

Roth LM (2004) The social psychology of tokenism: status and homophily processes on Wall Street. Sociological Perspectives 47, 189-214. 
Steinberg M, Donald K, Najman J and Skerman H (1996) Attitudes of employees and employers towards older workers in a climate of anti-discrimination. Australasian Journal on Ageing 15, 154-158.

Taylor P and Urwin P (2001) Age and participation in vocational education and training. Work, Employment \& Society 15, 763-779.

Urwin P (2006) Age discrimination: legislation and human capital accumulation. Employee Relations 28, $87-97$.

Van Dalen HP, Henkens K, Henderikse W and Schippers J (2010) Do European employers support later retirement? International Journal of Manpower 31, 360-373.

Van Dalen HP, Henkens K and Wang M (2015) Recharging or retiring older workers? Uncovering the age-based strategies of European employers. The Gerontologist 55, 814-824.

Van der Lippe T, Lippényi Z, Lössbroek J, Van Breeschoten L, Van Gerwen N and Martens T (2016) European Sustainable Workforce Survey [ESWS]. Utrecht, The Netherlands: Utrecht University.

Van Hek M, Kraaykamp G and Wolbers MHJ (2016) Comparing the gender gap in educational attainment: the impact of emancipatory contexts in 33 cohorts across 33 countries. Educational Research and Evaluation 22, 260-282.

Van Oorschot W and Jensen PH (2009) Early retirement differences between Denmark and The Netherlands. A cross-national comparison of push and pull factors in two small European welfare states. Journal of Aging Studies 23, 267-278.

Yap M and Konrad AM (2009) Gender and racial differentials in promotions: is there a sticky floor, a midlevel bottleneck, or a glass ceiling? Relations Industrielles/Industrial Relations 64, 593-619.

Yoshida Y and Smith MR (2005) Training and the earnings of immigrant males: evidence from the Canadian workplace and employee survey. Social Science Quarterly 86, s1, 1218-1241.

Cite this article: Lössbroek J, Radl J (2019). Teaching older workers new tricks: workplace practices and gender training differences in nine European countries. Ageing \& Society 39, 2170-2193. https://doi.org/ $10.1017 / \mathrm{S} 0144686 \mathrm{X} 1800079 \mathrm{X}$ 